\title{
CONSTRAINTS FOR ASSESSMENT OF PSYCHOMOTOR DOMAIN (READING SURAH AL-MAIDAH VERSES 2-3) IN GRADE 6 SDN 2 BANTARWUNI DURING THE COVID-19 PANDEMIC
}

\author{
Muhamad Restu Fauzi ${ }^{1}$, Isna Imroatuz Zakiyati ${ }^{2}$, Ahmad Qomarudin $^{3}$ \\ UIN Sunan Kalijaga, SDN 2 Bantarwuni \\ 19204010042@student.uin-suka.ac.id,isnaizakiya10@gmail.com
}

\begin{abstract}
Covid-19 has many negative effects on education. The government took an emergency policy in the form of school from home. Because of this policy, online teaching and learning activities are carried out from home. However, the reality in the field, such as what happened in SDN 2 Bantarwuni, there are several obstacles such as what happened in the psychomotor domain assessment process in reading surah al-Maidah verses 2-3. This study aims to: (1) Understand how the psychomotor domain assessment process in reading al-Maidah verse 2-3 at SDN 2 Bantarnuni; (2) Understand the conditions and constraints faced in the assessment of the psychomotor domain in reading al-Maidah verses 2-3 at SDN 2 Bantarwuni. This research is a qualitative field research. The method of data collection was done by observation at SDN 2 Bantarwuni and documentation. The results of this study: (1) The assessment process was carried out according to the procedure, except that there were some students who did not submit the assessment assignment; (2) The obstacles faced are the lack of effort from students and parents to collect assignments via the Whats App application or directly carry out face-to-face assessments at school.
\end{abstract}

Keywords: Assessment of Psychomotor Domain; the Covid-19 Pandemic; SDN 2 Bantarwuni

\section{INTRODUCTION}

Covid-19 has many negative effects on education. Many countries have decided to close schools and colleges. Dropout rates worldwide are increasing because of access to education becomes more difficult. While other critical needs such as health, air and sanitation are being resolved, the need for education cannot be overlooked because education has the same level of importance.

Global lockdown especially in educational institutions will cause major disruptions in student learning. These disruptions are disruption in learning, assessment and evaluation. In a lockdown situation, there is a cancellation of the plan 
to implement the teaching and learning activities in schools and it is replaced by another alternative in the form of implementing the teaching and learning activities at home. Home schooling is not only a big surprise to the parents, but also the social and learning lives of children. In this surprise, many parties were not ready, including the government, educators, students also parents of students.

The aim of Indonesia's national education is to bring society and the country towards the development of students' skills and character or a better attitude in order to become democratic and responsible citizens. The curriculum needs to be made to support the achievement of these goals. ${ }^{1}$ In 1956, the Bloom research team published Bloom's Taxonomy which clarified learning assessment items into 3 domains: the cognitive domain, the affective domain and the psychomotor domain. ${ }^{2}$ The current Indonesian curriculum, Kurrikulum 2013, seeks to emphasize knowledge, skills and attitudes, all of which are in line with the goals of Indonesian National Education.

Most of the cognitive domains (knowledge) of students are developed through classroom teaching. The affective domain component, which involves growth in feelings or emotional areas (attitudes), is developed through activities such as structured leadership group projects and learner development activities (extracurricular activities such as scouting). Whereas the psychomotor domain, commonly referred to as physical skills, is usually developed in a laboratory or training environment. $^{3}$

The psychomotor domain is a domain related to physical skills. The psychomotor domain is something that is demonstrated or made by students. The psychomotor domain also has goals related to manipulation, action and motor skills. Learning outcomes in the psychomotor domain are a continuation of cognitive and affective learning. This happens because after students learn the theories and have a good attitude, students can apply and show their skill abilities.

\footnotetext{
1 Anastasia Sastrikirana, “An Authentic Project-Based Assessment Model for Vocational High School Student Grade X”, in Indonesia Journal of English Studies, Vol. 1, No.2, September 2015, p. 151.

2 Benjamin S. Bloom, Taxonomy of Educational Objectives: Book 1 Cognitive Domain (Ann Arbor: Longmans, 1956), p. 7.

${ }^{3}$ Shahrizan Baharom et al, "Assessment of Domain in a Problem-Based Concrete Laboratory", in Journal of Enginering Science and Technology Special Issue on UKM Teaching and Learning Congress 2013, No. 1-10, Juni 2015, p. 2.
} 
During the global Covid-19 pandemic, the effects on education can have longterm implications for those who are most vulnerable. There is a real risk of regression for children who are studying basic subjects (reading, writing and arithmetic) as well as for prospective lecturers who are supposed to practice micro teaching or even direct teaching exercises on campuses but are constrained by the COVID-19 outbreak.

Extended school closures not only lead to loss of learning in the short term, but also cause loss of human resources and reduced economic opportunities in the long term. When the family finances are strained and the needs are increasing, there is a risk that children cannot participate in online learning activities or even drop out of school. The government has indeed provided an alternative solution to learning activities at school, i.e. studying at home online. For people who live in urban areas able to get access to internet services, there may be no obstacles in taking online learning. However, this policy cannot reach all segments of society, especially the marginalized and lower class' communities.

Educators must be good at racking their brains to solve this problem. Students who live in urban areas may not be so constrained by government recommendations to study online at home. Educators only need to carry out the teaching and learning process online such as carrying out the teaching and learning process before the COVID-19 era by including parental support in implementing teaching and learning activities and parental supervision on assignments given to students. However, students who live in the rural area or who cannot get internet access will be constrained. Educators must find other alternatives. The government has supported the home study program by launching alternative learning programs via television that are more accessible to rural communities or those who cannot get internet access. But the next problem is still going on. Not all parents of students in rural areas are aware of the importance of education. The parents assume that children who do not study at school mean that children are off from studying because the parents think that teaching is the duty of the teacher at school and parents are not responsible for teaching knowledge and skills to their children. This is a serious problem. Parents' awareness of the responsibility of educating must be increased 
immediately because if there is an obstacle when teachers cannot teach or supervise students in the COVID-19 pandemic or even on normal days outside of the epidemic conditions, parents can replace the teacher's position in providing knowledge.

SDN 2 Bantarwuni is one of the public elementary schools whose teaching and learning processes have been affected by the Covid-19 pandemic. Another obstacle also exists like in the learning assessment process both in the cognitive, affective and psychomotor domain. These constraints are, for example, in assessing the realm of practical skills in reading Surah al-Maidah in grade 6.

Based on the above background, the researcher wants to conduct a research entitled "Constraints for Assessment of Psychomotor Domain (Reading Surah alMaidah verses 2-3) in Grade 6 SDN 2 Bantarwuni during the Covid-19 Pandemic".

\section{METHOD}

The research method in this research uses qualitative methods. This type of research is field research which is located in SDN 2 Bantarwuni, Kembaran district, Banyumas regency, Central Java. The data source in this study is the primary data source which the researchers took directly from SDN 2 Bantarwuni using observation and documentation methods.

\section{Assessment of Psychomotor Domain and Its Scope}

Assessment of psychomotor domain is an assessment related to the skills or ability to act after students gain learning experience. Assessment of psychomotor domain is an assessment of actions or skills that are effectively used to gather information about the forms of behavior or skills that are expected to appear in students. Assessment of psychomotor domain is used by observing student activity in doing something. This assessment asks students to demonstrate and apply knowledge in context according to established criteria. Subjects related to the 
psychomotor domain are more oriented towards moving subjects and place more emphasis on physical reactions and hand skills. ${ }^{4}$

The psychomotor domain focuses on carrying out a series of motor activities to a certain level of accuracy, fluency, speed, or strength. Motor activity is based on cognitive understanding. In an educational setting, skills learning can be included in activities such as: Laboratory activities for science classes; Vocational activities; Physical education activities; Art activities; Activities using special equipment such as computers, projectors, videos, and others. ${ }^{5}$

In Kurrikulum 2013, the psychomotor domain is divided into 2 groups: concrete skills and abstract skills. Concrete skills are motor physical skills or real skills that are oriented towards students' physical skills and the use of tools. Meanwhile, abstract skills are mental skills or intangible skills that are oriented towards reasoning, processing, creating skills that focus on thinking skills without the help of tools.

According to Dave's taxonomy, the scope of concrete skills consists of 5 stages: imitation, manipulation, precision, articulation and naturalization. At the level of imitation, students only copy the actions of others, while in manipulation students reproduce activities from instructions or memories. In the stage of precision, students perform skills reliably and do not rely on assistance. Articulation is the adaptation and integration of skills to meet different situations. In naturalization, there is automatic and unconscious mastery of related activities and skills. ${ }^{6}$

Meanwhile, according to Elizabeth Simpson, the scope of concrete skills has 7 stages, namely: perception, set (readiness), guided responses, mechanism (directed movement), complex overt response (complex movement), adaptation, and origination (creativity) ${ }^{7}$

${ }^{4}$ Durotul Yatimah, "Implementation of Psychomotor Assessment on Life Skills Learning Program Package”, in Humanities \& Social Science Reviews, Vol. 8, No. 1, 2020, p. 172.

${ }^{5}$ Gowrishankar Kasilingam, Mritha ramalingam, and Elanchezian Chinnavan, "Assessment of Learning Domains to Improve Student's Learning in Higher Education", in Journal of Young Pharmacist, Vol. 6, No. 4, Jan-Mar 2014, p. 29.

${ }^{6}$ Gavin W. Henning and Darby Roberts, Student Affairs Assessment: Theory to Practice (Sterling: Stylus Publishing, 2016)

7 Elizabeth Simpson, The Classification of Educational Objectives, Psychomotor Domain (Urbana: University of Illinois, 1966), p. 25-30. 
As for taxonomy in the scope of abstract skills, according to Jeff Dyer there are several stages: associating (observing), questioning, observing (gathering information or trying to process), networking (reasoning) and experimenting (presenting). ${ }^{8}$

\section{Tools and techniques of performance appraisal}

According to Jay McTighe in Douglas G. Wren, performance appraisal is a learning activity or assessment that asks students to demonstrate their knowledge, understanding and skills. Performance appraisals produce tangible products and or performance that serve as evidence of learning. ${ }^{9}$

Oral exam is the most common example of performance-based assessments, but there are many other examples including experiments in science, oral presentations and the use of mathematics to solve real-world problems. The emphasis is on the skills performed by learners rather than just knowledge stored in the brain. ${ }^{10}$

Performance-based assessment is a better indicator because it allows the teacher to directly observe students applying the rules. When direct observation of student abilities is not possible, teachers should use assessments that indirectly measure student competencies. For teachers to make valid conclusions, the knowledge or behavior being assessed must be clearly defined and consistent with the assessment. ${ }^{11}$

In performance appraisal, teachers must provide instructions to their students about their assignments, and students must act according to these directions. With the performance assignments to be given, students will mobilize their imaginations, make concrete thoughts and designs, and they will have the important opportunity to take responsibility and gain confidence by closing them with satisfactory performance results. ${ }^{12}$

\footnotetext{
${ }^{8}$ Jeff Dyer, Hal Gregersen and Clayton M. Christensen, The Innovator's DNA: Mastering the Five Skills of Disruptive Innovators (Boston: Harvard Business Review Press, 2011), p. 41-133.

${ }_{9}^{9}$ Douglas G. Wren, Assessing Deeper Learning (Lanham: Rowman \& Littlefield, 2019), p. 31.

10 Robert L. Linn, Norman Edward Grondlund and Kevin M. Davis, Measurement and Assessment in Teaching (Princeton: Merrill, 2000), p. 259.

${ }^{11}$ Jacalyn Lea Lund dan Mary Fortman Kirk, Performance-Based Assessment for Middle and High School Physical Education (Champaign: Human Kinetics, 2020), p. 88.

12 Ali Göçer, “Türkçe Öğretiminde Ölçme ve Değerlendirme”, in İlkögrretimde Türkçe Öğretimi (Ankara: Pegem Akademi, 2009), p. 389.
} 
The performance appraisal task should be presented to students by the teacher in clear and simple language. Unclear task segments can cause students not to carry out job appraisal tasks properly. With complementary assessment and evaluation tools, students are evaluated not only by the "product" they produce, but also by their situation in the "process". If students experience incorrect or incomplete information about a performance task, the performance task they are about to perform can lead to inaccurate assessments or evaluations on teachers. Therefore, teachers should pay attention to the correct understanding of the explanation of the implementation of assignments by students. ${ }^{13}$

According to Popham, the factors to consider when evaluating performance appraisals are: ${ }^{14}$

1. Generalizability. Is there a high probability that student performance on assignments will generalize to comparable assignments?

2. Authenticity. Is the assignment similar to what students might face in the real world and not just face it in school?

3. Multiple foci. Does the assignment measure multiple learning outcomes, not just one?

4. Teachability. What are the tasks that students can become more proficient as a consequence of the teacher's instructional efforts?

5. Fairness. Is the assignment fair to all students - that is, does it avoid bias based on personal characteristics such as the student's gender, ethnicity, or socioeconomic status?

6. Feasibility. Are the assignments realistically implemented in terms of cost, space, time and equipment requirements?

7. Scorable. Is the assignment likely to elicit student responses that can be evaluated reliably and accurately?

he steps in preparing a performance appraisal can be structured as follows: ${ }^{15}$

13 Ali Göçer, Sevtap Arslan and Ceyda Çaylı, "Türkçe Eğitiminde Öğrenci Gelişim Durumunun Belirlenmesinde Süreç Temelli Tamamlayıc1 Ölçme Değerlendirme Yöntem ve Araçları”, in Süleyman Demirel Üniversitesi Sosyal Bilimler Enstitüsü Dergisi, No. 28, 2017, p. 266.

14 W. James Popham, Classroom Assessment (London: Pearson, 2017), p. 201-202. 
1. Identify the knowledge and skills that are expected to be mastered by students after students complete the task. The identification includes: Types of knowledge and skills; The level of use and attainment of these skills.

2. Design tasks for performance appraisal that allow students to demonstrate their thinking abilities and skills so that students are motivated to complete these tasks. The tasks that are designed need to consider the level of development of students as well as the depth and breadth of tasks.

3. Determine the passing grade criteria that will be used as benchmarks for a student to have achieved mastery in the expected knowledge or skills. The passing grade criteria must be detailed so that every aspects of the performance that is expected to be achieved by students have its own criteria.

There are three types of scoring methods that can be used to assess: holistic scoring, analytic scoring and primary traits scoring. Holistic scoring is based on a general assessment. Analytic scoring is based on an analytical assessment where the assessment is based on the elements that contribute. Primary traits scoring is based on an assessment of several dominant aspects. ${ }^{16}$

\section{Assessment of Reading Surah al-Maidah in Grade 6 SDN 2 Bantarwuni}

Assessment of reading surah al-Quran surah al-Maidah verses 2-3 uses online assessments. Face-to-face assessments are not possible because during the Covid-19 pandemic, the government adopted a policy of learning from home. Luckily, the students already have internet access at home through their parents' cellphones or borrow their neighbors' or friends'. Students were previously assigned to make a video recording of reading the Qur'an and then collected it to the teacher by WhatsApp application.

The teacher has notified the students about the things that will be used as an assessment: Reading fluency (makhroj) with a maximum score of 35; The accuracy of

15 Ömer Kutlu, C. Deha Doğan and İ Karakaya, Öğrenci Başarısınm Belirlenmesi: Performansa ve Portfolyoya Dayal Durum Belirleme (Ankara: Pegem Akademi, 2010), p. 34-35.

16 Arsaythamby Veloo, Noor Hashima Abd Aziz dan Aizan Yaacob, "The Most Suitable Scoring Method to Assess Essay Writing in ESL Classrooms", in Advances in Language and Literary Studies, Vol. 9, No. 4, August 2018, P. 20-21. 
reading (tajwid) with a maximum score of 35; and tone or rhythm with a maximum score of 30 , so that the maximum total score that students will get is 100 . If the students' final score is $90-100$, it means that students get very good score. If students get final score of 80-90, it means that they get good score, if students get final score of $70-80$, it means that the student get quite good score, but if the final score is below 70, it means that the student ability in reading the Koran is not good enough.

Table 1. The results obtained from the assessment are as follows:

Lembar Penilaian Kemampuan Membaca al-Qur'an

SDN 2 Bantarwuni

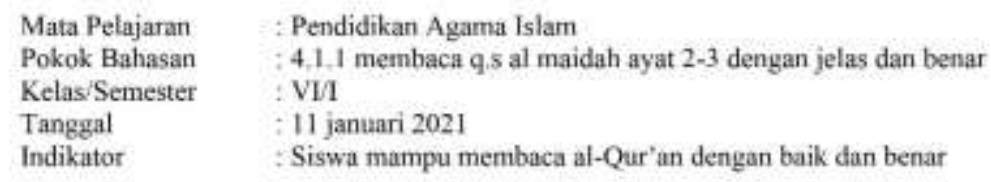

\begin{tabular}{|c|c|c|c|c|c|}
\hline No. & Nama & $\begin{array}{l}\text { Kelancaran } \\
\text { membaca } \\
\text { (makhroj) } \\
\text { (maksimal 35) }\end{array}$ & $\begin{array}{l}\text { Kebenaran } \\
\text { membaca } \\
\text { (Tajwid) } \\
\text { (maksimal 35) }\end{array}$ & $\begin{array}{l}\text { Nada/irama } \\
\text { (estetika) } \\
\text { (maksimal 30) }\end{array}$ & $\begin{array}{l}\text { Nilai } \\
\text { Akhir }\end{array}$ \\
\hline 1 & Alfin Aji Saputra & 30 & 30 & 25 & 85 \\
\hline 2 & Arkkey attar S. & 31 & 31 & 25 & 87 \\
\hline 3 & Kevin Andra P & 30 & 29 & 24 & 83 \\
\hline 4 & Rifki Pemana & 29 & 29 & 24 & 83 \\
\hline 5 & Rauf Nur Ardika & 29 & 28 & 24 & 82 \\
\hline 6 & Izaz Ningmatun K. & 31 & 30 & 25 & 86 \\
\hline 7 & Lulu Kirana Z. & 29 & 28 & 24 & 81 \\
\hline 8 & Hanif Candra P. & 27 & 26 & 23 & 76 \\
\hline 9 & Dika Saputra & 27 & 26 & 23 & 76 \\
\hline 10 & Gadis Rosalia I & 28 & 28 & 24 & 80 \\
\hline 11 & Muzdalifah A. P. & 28 & 28 & 24 & 80 \\
\hline 12 & Ramadhani D. M. & 27 & 27 & 23 & 77 \\
\hline 13. & Zulfa Aghni Ilmi & 28 & 28 & 23 & 79 \\
\hline 14 & Shelfi Mukti N. & 28 & 27 & 23 & 78 \\
\hline 15 & Alif Vando $\mathrm{S}$. & 29 & 27 & 23 & 79 \\
\hline 16 & Eva Nathania & 27 & 26 & 23 & 76 \\
\hline \multicolumn{6}{|l|}{17} \\
\hline \multicolumn{6}{|l|}{18} \\
\hline \multicolumn{6}{|l|}{19} \\
\hline \multicolumn{6}{|l|}{20} \\
\hline \multicolumn{6}{|l|}{21} \\
\hline \multicolumn{6}{|l|}{22} \\
\hline 23 & & & & & \\
\hline
\end{tabular}

Total anak: 23 (dengan 1 ABK)

Catatan guru

Pedoman nilai akhir:

Nilai $90-100=$ Amat Baik

Nilai $80-90=$ Baik

Nilai $70-80=$ Cukup Baik

Nilai $<70=$ Kurang Baik 
From the results of taking the scores above we can conclude that 7 out of 23 students got good scores in reading skills of al-Maidah verses 2-3 and 9 out of 23 children got quite good scores. Meanwhile, the other 7 children did not collect until the time limit.

According to homeroom teacher of sixth grade, there are indeed some students who do not have cellphones, but the homeroom teacher has advised the parents that if there are students or parents of students who do not have cellphones or internet access, they can ride with neighbors or come directly to school to collect assignments. Indeed, most of the parents at SDN 2 Bantarwuni work as scavengers and a small proportion of the parents who are more fortunate are working as boss scavengers. It can be said that the average income of parents from collecting waste is only enough to meet basic needs, while the budget for education is arguably very minimal. Many parents are less motivated to seriously send their children to school. They think that children could be able to read and count is enough, after that, children just had to work as waste collectors. They are less aware of the importance of education. They are reluctant to even borrow a cellphone to collect school assignments or come to school directly to conduct face-to-face assessments. Even though the teacher still goes to school even though the students learn from home.

\section{The Role of Educators and Parents in Learning during the Covid-19 pandemic}

Educators on the other hand must also be good at racking their brains to solve this problem. Educators must find other alternatives. Maybe by visiting their homes one by one, although of course it will be more troublesome than asking students to deposit videos via the WhatsApp application.

Not all parents of students in rural areas are aware of the importance of education. They assume that children who do not study at school mean that children are off from studying because the parents think that teaching is the duty of the teacher at school and parents are not responsible for teaching knowledge and skills to their children. This is a serious problem. Parents' awareness of the responsibility of educating must be increased immediately because if there are obstacles when teachers cannot teach or supervise students in the COVID-19 pandemic or even on normal 
days outside of the outbreak conditions, parents can replace the teacher's position in providing knowledge.

Parents must also participate for successful children's learning in the COVID-19 pandemic situation. Parents must fully encourage the teaching and learning process by fulfilling all the needs for learning in accordance with the provisions of the school. The school certainly considers the financial condition of each student's parents. Schools have considered the obstacles faced in rural schools ranging from the lack of awareness of parents towards education, supporting facilities (availability of internet networks or the ability to buy data packages or even cell phones) in learning and the competence of students at the periphery.

\section{CONCLUSION}

Assessment of the psychomotor domain in reading surah al-Maidah verses 2-3 in grade VI SDN 2 Bantarwuni during the Covid-19 pandemic was constrained by the condition of some parents who did not have internet access and the lack of parents' efforts to borrow cellphones to collect assignments or just take the child to school for face-to-face assessments.

Maybe it would be better for rural schools to implement teaching and learning activities in schools as usual than to implement teaching and learning activities at home. Rural areas usually have fewer cases of COVID-19 infection than cities or even no cases. For this reason, the central and local governments need to sort out which schools in which areas must carry out teaching and learning activities at home or at school. Schools in rural areas are usually in the green zone for the spread of COVID-19. For this reason, consider the availability of resources in the outskirt areas and the zoning status given to the rural areas (which are generally green zones), it is better if schools on the outskirts continue to carry out teaching and learning activities as usual rather than forcing learning at home but not at all effective.

The central and regional governments must immediately improve in development. Development (both public facilities and human resources) is the main point in boosting the country's progress. The construction of roads and 
communication networks (especially in rural areas) will trigger economic growth in the community and indirectly also raise public awareness of the importance of education. With the availability of better facilities, education will also run better.

From the perspective of the students themselves, students must also have learning awareness. They must be aware that they are in an unfavorable situation. Moving the teaching and learning process from school to home does not mean it is free and relax to feel like a vacation. In fact, students have to study harder because learning face-to-face with the teacher at school will not be worth learning online at home even though they are still with the same teacher. Students need to add other instruments in learning to replace the losing opportunity to ask questions to the teacher, for example by increasing reading activities via the internet. In the current condition of social restrictions, the internet is indeed a very important instrument in helping the implementation of teaching and learning activities. Students are expected to surf the internet more to increase their knowledge. Awareness needs to be instilled in each students.

In essence, all parties must be aware of the situation, be responsive and work together in the struggle to face the COVID-19 pandemic. The government, educators, students and parents of students must all try their best according to their position and abilities. The government as the holder of power must make strategic education policies according to the circumstances of each region. Educators as field executors must be able to create practical teaching methods in accordance with the circumstances of their students. Parents provide support in the form of providing things needed by students in implementing teaching and learning activities and providing supervision. Students as the core of education must study seriously because students are the hope for the future of the nation in the building of civilization. 


\section{REFERENCES}

Baharom, Shahrizan. "Assessment of Domain in a Problem-Based Concrete Laboratory", in Journal of Enginering Science and Technology Special Issue on UKM Teaching and Learning Congress 2013, No. 1-10, June 2015.

Bloom, Benjamin S. 1956. Taxonomy of Educational Objectives: Book 1 Cognitive Domain. Ann Arbor: Longmans.

Dyer, Jeff, Hal Gregersen, and Clayton M. Christensen. 2011. The Innovator's DNA: Mastering the Five Skills of Disruptive Innovators. Boston: Harvard Business Review Press.

Göçer, Ali. 2009. “Türkçe Öğretiminde Ölçme ve Değerlendirme”, in İlköğretimde Türkese Ögretimi. Ankara: Pegem Akademi.

Göçer, Ali, Sevtap Arslan, and Ceyda Çaylı. 2017. “Türkçe Eğitiminde Öğrenci Gelişim Durumunun Belirlenmesinde Süreç Temelli Tamamlayıcı Ölçme Değerlendirme Yöntem ve Araçları", in Süleyman Demirel Üniversitesi Sosyal Bilimler Enstitüsü Dergisi, No. 28, 2017.

Henning, Gavin W., and Darby Roberts. 2016. Student Affairs Assessment: Theory to Practice. Sterling: Stylus Publishing.

Kasilingam, Gowrishankar. Mritha Ramalingam, and Elanchezian Chinnavan. "Assessment of Learning Domains to Improve Student's Learning in Higher Education”, in Journal of Young Pharmacist, Vol. 6, No. 4, Jan-Mar 2014.

Kutlu, Ömer, C. Deha Doğan, and İ Karakaya. 2010. Öğrenci Başarısının Belirlenmesi: Performansa ve Portfolyoya Dayah Durum Belirleme. Ankara: Pegem Akademi.

Linn, Robert L. Norman Edward Grondlund and Kevin M. Davis. 2000. Measurement and Assessment in Teacbing. Princeton: Merrill.

Lund, Jacalyn Lea and Mary Fortman Kirk. 2020. Performance-Based Assessment for Middle and High School Physical Education. Champaign: Human Kinetics.

Sastrikirana, Anastasia. "An Authentic Project-Based Assessment Model for Vocational High School Student Grade X", in Indonesia Journal of English Studies, Vol. 1, No.2, September 2015.

Simpson, Elizabeth. 1966. The Classification of Educational Objectives, Psychomotor Domain. Urbana: University of Illinois.

Veloo, Arsaythamby. Noor Hashima Abd Aziz and Aizan Yaacob. "The Most Suitable Scoring Method to Assess Essay Writing in ESL Classrooms", in Advances in Language and Literary Studies, Vol. 9, No. 4, August 2018.

W. James Popham. 2017. Classroom Assessment. London: Pearson.

Wren, Douglas G. 2019. Assessing Deeper Learning. Lanham: Rowman \& Littlefield.

Yatimah, Durotul. "Implementation of Psychomotor Assessment on Life Skills Learning Program Package”, in Humanities \& Social Science Revienss, Vol. 8, No. 1, 2020. 